\title{
Association between multimeric adiponectin and free leptin index with atherogenic dyslipidemia in non-diabetic obese men
}

\author{
Candra Ninghayu, ${ }^{1,2}$ Andi Wijaya, ${ }^{1,2}$ Suryani As'ad ${ }^{3}$ \\ ${ }^{1}$ Postgraduate Program in Biomedical Science, Clinical Chemistry, Faculty of Medicine, Hasanuddin University, Makassar, Indonesia \\ ${ }^{2}$ Prodia Clinical Laboratory, Jakarta, Indonesia \\ ${ }^{3}$ Faculty of Medicine, Hasanuddin University, Makassar, Indonesia
}

\begin{abstract}
Abstrak
Latar belakang: Penelitian ini bertujuan menilai peran berbagai adiponektin dan indeks leptin bebas terhadap dislipidemia aterogenik pada pria obesitas sentral non diabetes.

Metode: Desain penelitian ini adalah potong lintang pada 120 pria obesitas sentral non-diabetes yang dilakukan di Jakarta. Parameter yang diukur adalah adiponektin total, adiponektin berat molekul tinggi, adiponektin berat molekul sedang, adiponektin berat molekul rendah, leptin, soluble leptin receptor, trigliserida, kolesterol HDL, kolesterol LDL dan apolipoprotein B (Apo B). Kriteria dislipidemia aterogenik adalah rendahnya kadar kolesterol HDL, disertai trigliserida dan small dense $L D L$ (sdLDL) yang tinggi. Kadar sdLDL didapat dari rasio kolesterol LDL / Apo B. Indeks leptin bebas adalah rasio leptin dengan soluble leptin receptor dengan menggunakan median sebagai titik dikotomi. Dilakukan krostabulasi untuk data kategorial. Hubungan antara adiponektin multimerik, indeks leptin bebas dengan lipid aterogenik dianalisis dengan uji Spearman, selanjutnya hasil interaksi keseluruhan parameter terhadap dislipidemia aterogenik dianalisis dengan regresi logistik ganda.
\end{abstract}

Hasil: Adiponektin berat molekul tinggi berkorelasi negatif secara bermakna dengan dislipidemia aterogenik $(p<0,05)$, sedangkan adiponektin berat molekul sedang dan adiponektin berat molekul rendah tidak berkorelasi $(p>0,05)$ dengan dislipidemia aterogenik. Indeks leptin bebas berkorelasi positif secara bermakna dengan dislipidemia aterogenik $(p<0,05)$. Odds Rasio (OR) adiponektin berat molekul tinggi terhadap kejadian dislipidemia aterogenik adalah 3,62 $(p<0,05)$, sedangkan risiko dislipidemia aterogenik pada subyek dengan indeks leptin bebas rendah adalah 4,57 ( $p<0,05)$.

Kesimpulan: Adiponektin berat molekul tinggi dan indeks leptin bebas berperan dalam meningkatkan risiko dislipidemia aterogenik. (Med J Indones 2011; 20:119-24)

\begin{abstract}
Background: To analyze the role of various adiponectin and free leptin index on the occurrence of atherogenic dislipidemia in non-diabetic central obese men

Methods: This is a cross-sectional study on 120 non-diabetic central obese men that was done in Jakarta. The measured indicators were total adiponectin, high molecular weight adiponectin (HMW adiponectin), medium molecular weight adiponectin (MMW adiponectin), low molecular weight adiponectin (LMW adiponectin), leptin, soluble leptin receptor, triglycerides, high-density lipoprotein cholesterol (HDL cholesterol), low density lipoprotein cholesterol (LDL cholesterol) and apolipoprotein B (Apo B). Atherogenic dyslipidemia was characterized by reduced level of HDL cholesterol, and high levels of triglyceride and small dense LDL (sdLDL). Ratio of LDL cholesterol and Apo B were calculated to get sdLDL. Free Leptin Index (FLI) was the ratio between total leptin and soluble leptin receptor (sOB-R), and median values were used as cut off to define high and low values of each parameter. Cross tabulation were done on categorical data. Relationships between multimeric adiponectin and free leptin index with atherogenic lipids were analyzed by using Spearman analysis. Further, the interaction of all indicators with the occurence of atherogenic dyslipidemia was analyzed using binary logistic regression.
\end{abstract}

Results: A negative correlation of HMW adiponectin with atherogenic dyslipidemia $(p<0.05)$, whereas there were no correlation between MMW adiponectin and LMW adiponectin with atherogenic dyslipidemia ( $p>0.05)$. Free Leptin Index was associated positively with atherogenic dyslipidemia $(p<0.05)$. Odds Ratio $(\mathrm{OR})$ of HMW adiponectin for the occurrence of atherogenic dyslipidemia was $3.62(p<0.05)$, where as OR of FLI with atherogenic dyslipidemia was $4.57(p<0.05)$.

Conclusion: HMW Adiponectin and FLI might contribute to atherogenic dyslipidemia in central obese non-diabetic males. (Med J Indones 2011; 20:119-24)

Key words: HMW adiponectin, LMW adiponectin, MMW adiponectin, total adiponectin

Obesity has become an epidemic throughout the world and poses significant health and economic burden to both developed and developing societies. Globally, the World Health Organization estimates that a billion of adults have a body mass index greater than $25 \mathrm{~kg} / \mathrm{m}^{2}$ and 300 million are obese with BMI over $30 \mathrm{~kg} / \mathrm{m}^{2}$. Recent study by Himpunan Correspondence email to: chandra_ninghayu@prodia.co.id
Studi Obesitas Indonesia Indonesian (Association of Obesity Study) on more than 6.000 subjects has shown that the prevalence of obesity was increased, $9.16 \%$ in men and $11.02 \%$ in women. The incidence will increase and can be a serious problem 20 years from now if obesity is not treated properly. The best way to diagnose obesity in clinical 
practice is to measure waist circumference. Diagnosing obesity is of great importance as excess in abdominal fat is tightly associated with metabolic risk factors. Atherogenic dyslipidemia is a constellation of metabolic risk factors that consist of: elevated triglycerides and small dense lowdensity lipoprotein (sdLDL) particles, plus low high-density lipoprotein (HDL)-cholesterol .1,2

Much of the recent work on obesity has highlighted the key role of adipose tissue as an endocrine organ that secretes a number of factors that mediate many of the vascular and metabolic complications of adiposity. The precise relationship between dyslipoproteinemia and adiposity are complex and undefined. Adipose tissue has recently been shown to secrete a variety of bioactive peptides, called adipocytokines that can potentially impact on glucose and lipid metabolism. These adipocytokines include adiponectin, leptin, resistin, interleukin-6 (IL-6), and tumor necrosis factor $\alpha(\mathrm{TNF}-\alpha){ }^{3,4}$

Adiponectin circulates in the blood as several oligomeric complexes, including trimer (low molecular weight, LMW), hexamer (medium molecular weight, MMW) or multimer (high molecular weight, HMW) forms, and the HMW form has been reported to be the most active form of this hormone. There are very little data that assess the metabolic significance of adiponectin multimeric forms. There was one recent article that showed that administration of HMW but not LMW adiponectin lowered blood glucose concentration in mice. In contrast, other studies have shown that MMW (hexamer) and HMW adiponectin are equally effective in activating nuclear factor- $\kappa \mathrm{B}$ and that both adiponectin monomer and trimer are capable of stimulating adenosine monophosphateactivated protein kinase (AMPK) whereas LMW and HMW adiponectin produce no effect. ${ }^{5,6}$

Leptin, an appetite-regulating hormone, circulates both in free form and bound to macromolecules. A study on the percentage of bound and free leptin has indicated that a significantly greater proportion of total leptin circulates in the bound form in lean compared with obese subjects. Interestingly one of the isoforms of the leptin receptor is a putative soluble leptin receptor (sOB-R) that could act as a binding protein. The sOB-R plays an important role in the pathophysiology of energy homeostasis in rodents and humans. Thus, understanding the regulation of circulating sOB-R and free leptin in humans may have important physiological and therapeutic implications for human obesity and eating disorders. ${ }^{7,8}$

Adiponectin, one of the adipokine, has shown to be an important marker for metabolic disorders and the expression is reduced in obese mice or humans. In obesity, the levels of leptin are increased but the levels of sOB-R are decreased compared to the lean control.
Reduction of body weight through diet or surgical procedures significantly increases the concentration of circulating sOB-R and, thus, increases the fraction of bound leptin. Thus, sOB-R might act as modulating factor of leptin action and plays an important role in leptin resistance. Nevertheless, levels of sOB-R can provide the information of free leptin; the free leptin index (FLI) is defined as the ratio of leptin to sOB-R, which may be a more accurate determinant of leptin function. ${ }^{9,10,11}$ We therefore investigated the relationship between adiponectin oligomers, free leptin index with atherogenic dyslipidemia.

\section{METHODS}

This is a cross-sectional study that which conducted to observe the correlation between HMW, MMW and LMW adiponectin, and free leptin index with the atherogenic dyslipidemia. Data collection was commenced in May 2009 and completed in Juli 2009. The study proposal was approved by the Health Research Ethics Committee of the Faculty of Medicine, University of Hasanuddin, Makassar, Indonesia, and all participants have given written informed consent.

\section{Study population}

A total of 120 males, aged $30-60$ years old, who were apparently healthy, having central obesity (waist circumference $>90 \mathrm{~cm}$ ), normal blood pressure, and willing to follow the study protocol, were considered eligible to be included in the study. Subjects were recruited from Cikarang and Prodia clinical laboratories in Jakarta. Those who are consuming steroids; or had been treated with anti-inflammatory drugs, statin or thiazolidinedione for at least 3 weeks; or had diabetes mellitus, liver dysfunction, kidney dysfunction, hypertension, or fever were excluded from this study.

\section{Anthropometric measurement}

Body weight (BW) was measured in kilograms to the nearest $0.1 \mathrm{~kg}$, with light clothes on, using a beam scale Tanita. Height (Ht) was measured in centimeters to the nearest $0.1 \mathrm{~cm}$, in standing position, using a microtois (stature meter). Waist circumference was measured in centimeters to the nearest $0.1 \mathrm{~cm}$, using a flexible nonelastic tape made by Roche (Roche, Switzerland). Waist circumference was measured at the midway region between the lowest rib margin and the iliac crest, in standing position with abdomen relaxed, feet together and weight equally divided over both legs.

\section{Blood pressure measurement}

Blood pressure was measured using a sphygmomanometer (Riester). Subjects were seated for at least 5 minutes before the measurement. The first and fifth 
Korotkoff sounds were taken as systolic and diastolic blood pressure, respectively.

\section{Biochemical assessments}

A blood sample was collected from each subject after 12-14 hours overnight fasting in plain tubes. Serum was separated immediately by centrifugation and aliquots were frozen at $-20^{\circ} \mathrm{C}$ for subsequent batched analyses of various adiponectins, leptin, and soluble leptin receptor. The various adiponectins were determined using enzyme-linked immunosorbent assay (ELISA) method (Sekisui Medical Co Ltd, Japan). Total adiponectin, HMW adiponectin and combined MMW and HMW adiponectin were directly measured. The concentration of MMW adiponectin can be calculated by subtracting the concentration of HMW adiponectin from combined concentration of HMW and MMW adiponectin. The concentration of LMW adiponectin can be calculated by subtracting the combined concentration of MMW adiponectin plus HMW adiponectin from the concentration of total adiponectin. Leptin and sOB-R were measured with enzyme immunoassay using Quantikine (R\&D Systems Inc, USA). Liver function was considered normal based on serum alanine amino transferase (ALT), aspartate amino transferase (AST) that were determined using the International Federation of Clinical Chemistry (IFCC) method and reagent manufactured by Roche (Mannheim, Germany), and creatinine was determined by enzymatic techniques using reagents manufactured by Roche (Mannheim, Germany). The hexokinase method was used to determine fasting blood glucose, using reagents manufactured by Roche (Mannheim, Germany). Homogenous method was used to determine HDL-cholesterol, using reagents manufactured by Daiichi Tokyo-Japan. Triglyceride in blood serum sample was measured by GPOPAP method using reagents manufactured by Roche (Mannheim, Germany). Apo B in blood serum sample was measured by immunoturbidimetric method using reagents manufactured by Bayer.

By determining the concentration of plasma apo B, we could determine the amount of sdLDL particles, using the ratio of LDL cholesterol/apoB (LDL cholesterol concentration was measured with direct method), the ratio of LDL cholesterol/apoB $<1.2$, indicated sdLDL in the circulation. Free leptin index was defined as the ratio of leptin to sOB-R. Atherogenic dyslipidemia was defined as the concomitant presence of triglycerides $\geq 150 \mathrm{mg} / \mathrm{dL}, \mathrm{HDL}$-cholesterol $<$ $40 \mathrm{mg} / \mathrm{dL}, \mathrm{LDL}-\mathrm{cholesterol/apo} \mathrm{B}<1.2$.

\section{Data analysis}

Statistical analyses were performed using SPSS for windows 13.0 (SPSS Inc., Chicago, IL, USA). Distributions of continuous variables were assessed for normality using the Kolmogorov-Smirnov test. For continuous variables with normal distribution such as anthropometric and biochemical measures, data were presented as mean \pm SD. The association between various measures i.e. multimeric adiponectin and free leptin index with atherogenic lipids were analyzed. The analysis was done with Pearson correlation when the data were normally distributed and Spearman's rho correlation when the data were not normally distributed. All tests were considered significant at $p<0.05$. Further, the interaction of all indicators with the occurrence of atherogenic dyslipidemia was analyzed using binary logistic regression analysis, in order to assess odds ratio (OR) for the risk of atherogenic dyslipidemia.

\section{RESULTS}

This study was carried out exclusively on male subjects to prevent any biases regarding hormonal effects found on female subjects. Table 1 showed general description of subjects' baseline characteristics.

Table 1. Description of subjects' baseline characteristics

\begin{tabular}{llll}
\hline $\begin{array}{l}\text { Characteristics } \\
\mathrm{n}=120\end{array}$ & Median & Mean & SD \\
\hline Age (year) & 38.0 & 38.6 & 6.13 \\
Waist circumference $(\mathrm{cm})$ & 96.0 & 97.6 & 5.87 \\
SBP $(\mathrm{mmHg})$ & 110 & 112 & 10.18 \\
DBP $(\mathrm{mmHg})$ & 70 & 74 & 7.77 \\
AST $(\mathrm{U} / \mathrm{L})$ & 26.0 & 28.7 & 8.16 \\
ALT $(\mathrm{U} / \mathrm{L})$ & 36.0 & 37.6 & 14.94 \\
Creatinine $(\mathrm{mg} / \mathrm{dL}$ & 1.10 & 1.08 & 0.16 \\
Fasting Blood Sugar $(\mathrm{mg} / \mathrm{dL})$ & 74.0 & 89.7 & 8.85 \\
Adiponectin $(\mu \mathrm{g} / \mathrm{mL})$ & 3.16 & 3.15 & 0.92 \\
HMW Adiponectin $(\mu \mathrm{g} / \mathrm{mL})$ & 0.84 & 1.01 & 0.64 \\
MMW Adiponectin $(\mu \mathrm{g} / \mathrm{mL})$ & 0.60 & 0.61 & 0.35 \\
LMW Adiponectin $(\mu \mathrm{g} / \mathrm{mL})$ & 1.42 & 1.53 & 0.67 \\
Leptin $(\mathrm{ng} / \mathrm{mL})$ & 9.74 & 10.18 & 3.95 \\
sOB-R (ng/mL) & 17.89 & 18.45 & 4.28 \\
FLI & 0.56 & 0.58 & 0.25 \\
Triglyceride $(\mathrm{mg} / \mathrm{dL})$ & 165.0 & 181.0 & 89.63 \\
HDL cholesterol $(\mathrm{mg} / \mathrm{dL})$ & 43.0 & 44.2 & 8.04 \\
LDL cholesterol $(\mathrm{mg} / \mathrm{dL})$ & 137.9 & 138.2 & 37.11 \\
Apo B $(\mathrm{mg} / \mathrm{dL})$ & 104.0 & 103.6 & 21.03 \\
LDL cholesterol/Apo B & 1.34 & 1.33 & 0.19 \\
\hline
\end{tabular}

$\mathrm{SBP}=$ systolic blood pressure $\mathrm{DBP}=$ diastolic blood pressure $; \mathrm{AST}=$ aspartate amino transferase, $\mathrm{ALT}=$ alanine amino transferase; $\mathrm{HMW}=$ high molecular weight; MMW = medium molecular weight; LMW = low molecular weight; sOB-R = soluble leptin receptor; FLI= free leptin index; $\mathrm{HDL}=$ high density lipoprotein; $\mathrm{LDL}=$ low density lipoprotein; Apo B= apolipoprotein B.

Data grouping of low and high concentration of total adiponectin was based on previous study by Ebinuma et al. with cut off value $2.54 \mu \mathrm{g} / \mathrm{mL}$, HMW adiponectin $0.60 \mu \mathrm{g} / \mathrm{mL}$, MMW adiponectin $0.77 \mu \mathrm{g} / \mathrm{mL}$, LMW adiponectin $1.17 \mu \mathrm{g} / \mathrm{mL} .{ }^{12}$ Cut off value of leptin, sOB-R and FLI were based on their median to group them into lower and higher concentration groups. 
There were very weak but significant correlation between HMW adiponectin and triglyceride $(\mathrm{r}=-0.290$, $\mathrm{p}=0.001)$, HMW adiponectin and HDL cholesterol $(\mathrm{r}=$ $0.211, p=0.020$ ). No significant correlation between HMW adiponectin and sdLDL $(r=0.175, \mathrm{p}=0.056)$. Free Leptin Index was associated positively with atherogenic dyslipidemia $(\mathrm{p}<0.05)$.

Table 2 presents the odds ratio (OR) and $\mathrm{p}$ for the development of atherogenic dyslipidemia. We found the following risk of atherogenic dyslipidemia events: low levels of HMW adiponectin (OR 3.62, p=0.036), and high levels of FLI (OR 4.57, $\mathrm{p}=0.029)$. Furthermore, no significant correlation was observed between MMW adiponectin $(\mathrm{p}=0.676)$ and LMW adiponectin $(\mathrm{p}=0.879)$ with atherogenic dyslipidemia.

Table 2. Logistic regression analysis of HMW adiponectin, MMW adiponectin, LMW adiponectin and free leptin index with atherogenic dyslipidemia

\begin{tabular}{lllll}
\hline \multirow{2}{*}{ Variable } & \multirow{2}{*}{ OR } & $\mathrm{p}$ & \multicolumn{2}{c}{$95 \% \mathrm{CI}$} \\
\cline { 4 - 5 } & & & Lower & Upper \\
\hline HMW adiponectin & 3.62 & 0.036 & 1.090 & 12.027 \\
MMW adiponectin & 0.75 & 0.676 & 0.197 & 2.866 \\
LMW adiponectin & 1.11 & 0.879 & 0.300 & 4.086 \\
FLI & 4.57 & 0.029 & 1.164 & 17.947 \\
\hline
\end{tabular}

$\mathrm{HMW}=$ high molecular weight, $\mathrm{MMW}=$ medium molecular weight, $\mathrm{LMW}=$ low molecular weight; FLI = free leptin index

\section{DISCUSSION}

Our present study showed that there were very weak, but significant correlations between HMW adiponectin with triglyceride and HDL cholesterol. Adiponectin is an adipocytokine that may have an impact on lipid metabolism and a link to obesity. Plasma adiponectin was strongly associated with markers of triglyceride rich lipoprotein (TRL) metabolism. Recent data demonstrated that adiponectin may reduce plasma triglyceride by increasing VLDL catabolism partly by increasing lipoprotein lipase (LPL) and VLDL receptor expression in skeletal muscle. Adiponectin may also decrease the accumulation of triglycerides in skeletal muscle by enhancing fatty acid oxidation through activation of AMP kinase. Chan et al. demonstrated that plasma adiponectin was positively associated with HDL-cholesterol and apolipoprotein A-I (apoA-I) and negatively associated with HDL-apoA-I fractional catabolic rate. Kinetic studies have previously shown that enhanced HDL-apoA-I clearance is directly dependent on the triglyceride enrichment of HDL and on the activity of hepatic lipase (HL). In central obesity, hepatic overproduction of VLDL together with decreased LPL activity results in expansion in the
VLDL-triglyceride pool and enhances cholesteryl ester transfer protein (CETP)-mediated heteroexchange of neutral lipids among lipoproteins, leading to increased HDL-triglyceride concentration. Accordingly, lower adiponectin levels may enhance the catabolism of HDL-apoA-I by an increase in the lipolysis of HDLtriglyceride (owing to increased hepatic lipase activity) and the dissociation of apoA-I from the HDL particles. The hypercatabolism of apoA-I may have a more dominant effect on HDL concentration. ${ }^{13}$

We also found in this study that there was very weak, but significant positive correlation between HDLcholesterol with HMW adiponectin, which suggests that the relationship between adiponectin and HDLcholesterol is primarily driven by HMW adiponectin rather than total adiponectin. The HDL-cholesterol is basically generated from lipid-free apolipoprotein A-I or lipid-poor pre $\beta-1-H D L$ as precursors. These precursors are partially produced by the liver, and it is well known that adiponectin oligomers specifically affect liver metabolism. ${ }^{14}$ We also found in this study, that there was no correlation between HMW adiponectin with sdLDL, indicating that HMW adiponectin did not influence sdLDL directly.

Increased central fat accumulation is considered a key pathophysiological feature of the atherogenic dyslipidemia. The risk of atherogenic dyslipidemia was highlighted in the present study by multivariate analysis. We performed logistic regression in order to asses the possible independent associations between atherogenic dyslipidemia with oligomeric adiponectin and free leptin index.

The results showed that HMW adiponectin had negative correlation with atherogenic dyslipidemia. It is apparent that the risk of subject with HMW adiponectin $<0.60$ $\mu \mathrm{g} / \mathrm{mL}$ to develop atherogenic dyslipidemia was 3.62 times those with HMW adiponectin $\geq 0.60 \mu \mathrm{g} / \mathrm{mL}$. We found no correlation between MMW adiponectin and LMW adiponectin with atherogenic dyslipidemia. Regulation of oligomeric complex formation of adiponectin is recognized as an important mechanism modulating the biological functions of these adipokines and might improve their protective properties. From studies in mice, which we get much of our understanding, it appears that once in the circulation, adiponectin oligomers are extremely stable and do not undergo exchange from one form to another, even in the face of an insulin or glucose challenge. Pajvani UBX et al ${ }^{16}$ said, circulating HMW adiponectin has a longer half-life than LMW adiponectin (9 vs. $4.5 \mathrm{~h}$ ) although HMW multimers may be cleared more rapidly than LMW adiponectin following metabolic challenges. 
A recombinant form of adiponectin that is unable to form oligomers larger than trimers and is sensitive to proteolytic cleavage following secretion appears to be more biologically active than HMW adiponectin and subject to more rapid clearance from the circulation. Together with the above observations that suggest an important role for HMW adiponectin in insulin sensitivity, these findings have led to the proposal that in response to metabolic challenge, HMW adiponectin may be converted to a biologically active form, through reduction and proteolytic cleavage. ${ }^{15}$ One possible explanation of the underlying mechanisms may be the higher affinity of HMW adiponectin to collagen in the vascular wall, compared to LMW or MMW forms, thus possibly exerting better repair on injured vessels. ${ }^{16}$

The data obtained from this study revealed that there was a positive correlation between FLI and atherogenic dyslipidemia among the central obese men. Leptin circulates not only in its free form, but also in a complexed form with the sOB-R. The sOB-R is the main leptin binding protein and the association between the serum leptin and sOB-R provides a measure of the FLI, which is a more accurate determinant of leptin function. The sOB-R may act as a negative regulator of leptin activity and it may maintain a pool of available bioactive leptin by binding and delay its clearance from the circulation. It has been suggested that in obese men the majority of leptin circulates in free form presumably bioactive protein and thus obese men are resistant to free leptin. The reduction in SOB-R concentrations in obese men may reflect down regulation of hypothalamic leptin receptor production as a result of an increase in the circulating leptin and might be an important factor in leptin resistance. According to Kratzsch et al., ${ }^{17}$ the average binding affinity of the sOB-R for leptin is in the same range as the binding affinity of leptin for its membrane receptor, the soluble form is capable of modulating leptin's action. This modulation may occur via different mechanisms. First, excess of sOB-R may inhibit leptin binding to membrane receptors by competing directly with its ligand. Second, the sOB-R may remarkably delay the clearance of leptin by binding leptin. The latter has been proven in rats, where the halflife of leptin-sOB-R complexes is almost 20-fold longer compared with that of the free hormone. If we hypothesize that the FLI indeed reflects the level of free leptin, then it is assumable that SOB-R modulates the function of leptin. ${ }^{17,18}$

In conclusion, our study showed that low HMW adiponectin and elevated FLI might contribute to atherogenic dyslipidemia in central obese non-diabetic males. Therefore, measurement of HMW adiponectin serum concentration and FLI will be useful in predicting the risk of atherogenic dyslipidemia in central obese non-diabetic patients.

\section{Ackowledgments}

We thank Prodia Foundation for Research and Training for the invaluable support in conducting the many procedures of this research.

\section{REFERENCES}

1. Lenz A, Diamond Jr FB. Obesity: the hormonal milieu. Curr Opin Endocrinol Diabetes Obes. 2008;15:9-20.

2. Grundy SM.Obesity, metabolic syndrome, and cardiovascular disease. J Clin Endocrinol Metab. 2004; 89: 2595-600.

3. Goldstein BJ, Scalia R. Adiponectin: A novel adipokine linking adipocytes and vascular function. J Clin Endocrinol Metab. 2004; 89: 2563-8.

4. Chan DC, Watts GF, Ng TWK, UchidaY, Sakai N, Yamashita $\mathrm{S}$, et al. Adiponectin and other adipocytokines as predictors of markers of triglyceride-rich lipoprotein metabolism. Clin Chem. 2005; 51: 578-85.

5. Narita K, Murata T, Hamada T, Takahashi T, Kosaka H, Sudo $\mathrm{S}$, et al. Adiponectin multimer distribution, not absolute amount of plasma, correlates with depression severity in healthy elderly subjects. Prog Neuro-Psychoph. 2007; 32: 124-7.

6. Castro CL, Luo N, Wallace P, Klein RL, Garvey WT. Adiponectin multimeric complexes and the metabolic syndrome trait cluster. Diabetes. 2006; 55: 249-59.

7. Ogier V, Ziegler O, Mejean L, Nicolas JP, KrongradAS. Obesity is associated with decreasing levels of the circulating soluble leptin receptor in humans. Int J Obes. 2002; 26: 496-503.

8. Chan JL, Bloher S, Yiannakouria N, Suchard MA, Kratzsch J, Mantzoros CS. Regulation of circulating soluble leptin receptor levels by gender, adiposity, sex steroids, and leptin, Diabetes. 2002; 51: 2105-12.

9. Schraw T, Wang ZV, Halberg N, Hawkins M, Scherer PE. Plasma adiponectin complexes have distinct biochemical characteristics. Endocrinology. 2008; 149: 2270 - 82.

10. Sandhofer A, Laimer M, Ebenbichler CF, Kaser S, Paulweber B, Patsch JR. Soluble leptin receptor and soluble receptorbound fraction of leptin in the metabolic syndrome, Obes Res. 2003; 11: 760-8.

11. Nobili V, Manco M, Ciampalini P, Diciommo V, Devito R, Piemonte F, et al. Leptin, free leptin index, insulin resistance and liver fibrosis in children with non-alcoholic fatty liver disease. Eur J Endocrinol. 2006; 155: 735-43.

12. Ebinuma H, Miyazaki O, Yago H, Hara K, Yamauchi T, Kadowaki T. A novel elisa system for selective measurement of human adiponectin multimers by using proteases. Clin Chem Acta. 2006; 20: 1-7.

13. Chan DC, Barrett PHR, Ooi EMM, Ji J, Chan DT, Watts GF. Very low density lipoprotein metabolism and plasma adiponectin as predictors of high-density lipoprotein apolipoprotein A-I kinetics in obese and nonobese men. J Clin Endocrinol Metab. 2009; 94: 989-97.

14. Bobbert T, Rochlitz H, Wegewitz U, Akpulat S, Mai $\mathrm{K}$, Weickert MO, et al. Changes of adiponectin oligomer composition by moderate weight reduction. Diabetes. 2005; 54: 2712-9.

15. Whitehead JP, Richards AA, Hickman IJ, Macdonald GA, Prins JB. Adiponectin - a key adipokine in the metabolic syndrome. Diab Obes Metab. 2006; 8: 264-80. 
16. von Eynatten M, Humpert PM, Bluemm A, Lepper PM, Andreas $\mathrm{H}$, Allolio B, etal.High-molecularweightadiponectin is independently associated with the extent of coronary artery disease in men. J Atheroscler. 2008;199:123-8.

17. Kratzsch J, Lammert A, Bottner A, Seidel B, Mueller G, Thiery J, et al. Circulating soluble leptin receptor and free leptin index during childhood, puberty, and adolescence. J Clin Endocrinol Metab. 2002; 87: 4587-94.

18. El Shebina SM, Ghattas LA, Mohamed HI, Moaty MIA, Tapozada ST, Hanna ML. Circulating concentrations of leptin hormone, soluble leptin receptor and free leptin index in obese Egyptian woman before and after diet therapy. J Med Sciences. 2009; 9: 219-26. 